\title{
Estimation of Evaporation using Daily and Ten-Minute Class-A Pan Data from Automatic Measuring Pressure Sensor Instrument at Tharandt, Germany
}

\author{
Antensay Mekoya ${ }^{1 *}$, Christian Bernhofer ${ }^{2}$ and Uta Moderow ${ }^{2}$ \\ 1National Meteorology Agency (NMA), Ethiopia
}

2Technische Universität Dresden, Germany

Submission: April 08, 2019; Published: April 30, 2019

*Corresponding author: Antensay Mekoya, NMA of Ethiopia, Ethiopia

\section{Abstract}

Evaporation is major component of global water cycle and water balance of a small/large irrigation area, reservoir or lake, and a catchment. In this study, evaporation from Class-A pan ( $\left.\mathrm{E}_{\mathrm{p}}\right)$ for the years from 2004 to 2013 at Tharandt, Germany is calculated and analyzed using daily and ten-minute Class-A pan water level data from automatic measuring pressure sensor instrument.

Daily $\mathrm{E}_{\mathrm{p}}$ is first calculated at two different times; at 7 a.m. and at midnight. Because daily $\mathrm{E}_{\mathrm{p}}$ calculated at 7 a.m. had shown less errors as it had fewer negative values ( $\mathrm{n}=43$ out of a total of 2145 values) than $\mathrm{E}_{\mathrm{p}}$ calculated at midnight ( $\mathrm{n}=84$ out of a total of 1971 values); $\mathrm{E}_{\mathrm{p}}$ calculated at 7a.m. is selected for the calculation of $E_{p}$. The correlation between $E_{p}$ calculated at midnight and $E_{p}$ calculated at 7a.m. was 'very good' $\left(R^{2}=\right.$ $\left.0.87, \mathrm{MSE}=0.32 \mathrm{~mm} \mathrm{~d}^{-1}\right)$. Therefore, $\mathrm{E}_{\mathrm{p}}$ calculated at midnight is used for filling as well as for correcting $\mathrm{E}_{\mathrm{p}}$ calculated at 7 a.m. values. Accordingly, missing values of daily $E_{p}$ at 7 a.m. are filled using $0.908 \times$ daily $E_{p}$ at midnight values +0.385 (Eq. 7). In Eq. 7, the cause for non-zero offset (0.385) could be instrument error. Assuming no instrument error, out of 1836 days, $\mathrm{E}_{\mathrm{pd}}$ which is the difference between 7a.m. and midnight $\mathrm{E}_{\mathrm{p}}$ (see Figure 1) was larger than zero for 1184 days ( $64.5 \%$ of the days). This means out of 1836 days, for $64.5 \%$ of the days next day 'night time' $E_{p}$ was greater than its previous day 'night time' $\mathrm{E}_{\mathrm{p}}$. Also, for at least 54 days $\left|\mathrm{E}_{\mathrm{pd}}\right| \leq 1.5 \mathrm{~mm} \mathrm{~d}^{-1}$ which means that the 'night time' daily $\mathrm{E}_{\mathrm{p}}$ had to be $\geq 1.0 \mathrm{~mm} \mathrm{~d}^{-1}$.

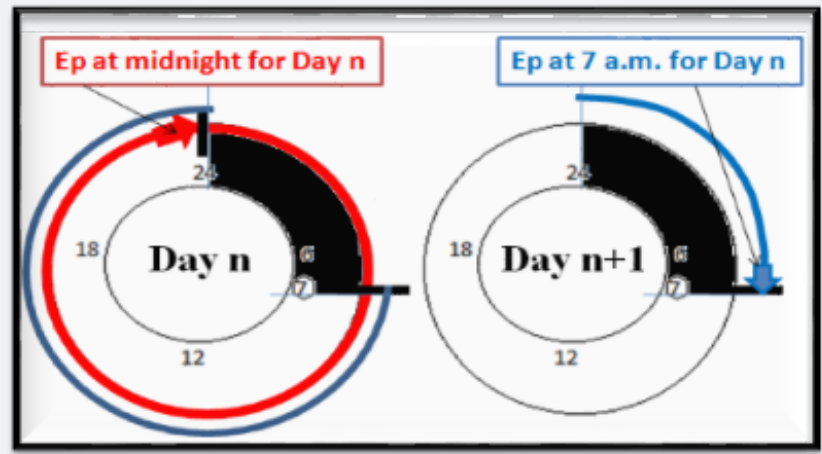

Figure 1: Understanding $E_{p d}$ which is daily $E_{p}$ at 7 a.m. ('blue') minus daily $E_{p}$ at midnight ('red') for day $n$.

Finally, 2098 daily values of $\mathrm{E}_{\mathrm{p}}$ are calculated from March to November for the available data; however, only the summer half year (April to September, $\mathrm{n}=1702$ ) values of $\mathrm{E}_{\mathrm{p}}$ are mainly used for most of the analysis.

Generally, the accuracy of the self-recording ten-minute and daily water level measurements from Class-A pan at Tharandt from 2004 to 2013 can be considered as very good. However, the measurement should be carefully checked as it might have sensitivity to other than pressure or water depth difference in the pan. Hence, the sensitivity of the pressure sensor instrument at 7a.m. and at midnight for same pressure (depth of pan water) might have slight difference.

Keywords: Tharandt; Class-A pan Evaporation ( $\left.\mathrm{E}_{\mathrm{p}}\right) ; \mathrm{E}_{\mathrm{p}}$ at 7 a.m. and at midnight, $\mathrm{E}_{\mathrm{pd}}$

Abbreviations: $E_{p}$ : Class-A Pan Evaporation ( $\left.E_{p}\right)$; Epd: $E_{p}$ at 7a.m. minus $E_{p}$ at midnight; ET: Evapotranspiration; V: Water Level at 7 a.m.; P: Precipitation at 7a.m.; V': Water Level at Midnight; RF: Precipitation at Midnight; NSE: Nash-Sutcliffe Efficiency; MAE: Mean Absolute Error; RMSE: Root Mean Square Error; RSR: RMSE-Observations Standard Deviation Ratio; MPE: Mean Percent of Error; 'night time': The Time between Midnight and 7 a.m. 


\section{Introduction}

Measured and estimated evaporation data has been in use by agricultural, hydrological, hydro meteorological, irrigation and soil and water conservation applications. Evaporation or evapotranspiration (ET) which is a major component of the global water cycle and the hydrologic budget or water balance of small or large irrigation area, reservoir or lake and a catchment is important consumer of energy. On average, across all continents about $70 \%$ of precipitation reaching the land surface evaporates; in dry regions (e.g., Australia) this ratio is higher and can reach up to $90 \%$ and in Europe to approximately $60 \%$ of the annual rainfall (Nova'k 2012 \& Baumgarter and Reichel, 1975) [1,2].

This article describes the methods used for estimation of evaporation from Class-A pan in a very humid temperate region (Tharandt, Germany).

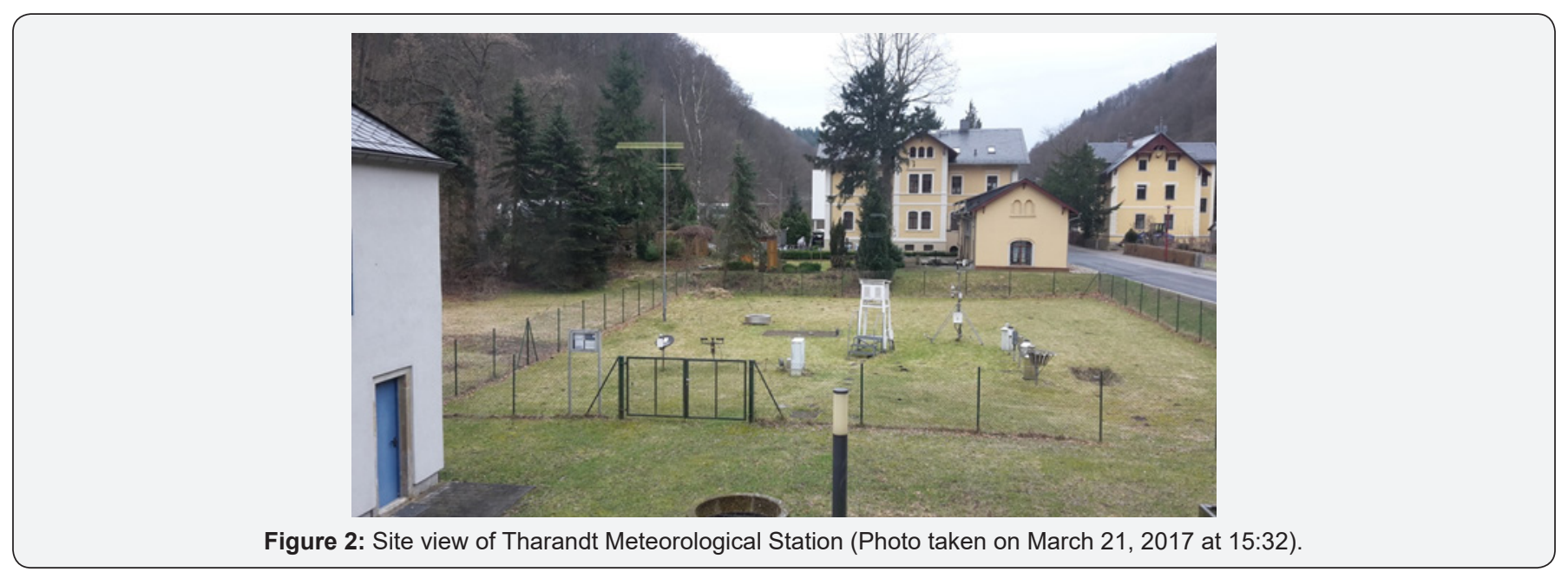

\section{Materials and Methods}

The station is situated in-flat and grass covered area and fulfils the WMO standard for meteorological measurements. This station has special characteristics because it is situated at the bottom of a V-shaped valley and close to an asphalt road, buildings and the Weißeritz River (see Figure $2 \& 3$ ). Therefore, it has a reduced sky view factor and consequently sunshine may comparatively reaches the area late in the morning and leaves earlier in the evening resulting in lower sunshine hours. Due to high shelter effects at low level, it is expected that the wind speed at $2 \mathrm{~m}$ (which was derived from the wind speeds at $3 \mathrm{~m}$ and at $10 \mathrm{~m}$ ) would have been higher than real values (if actual measurement had been conducted at $2 \mathrm{~m}$ height).

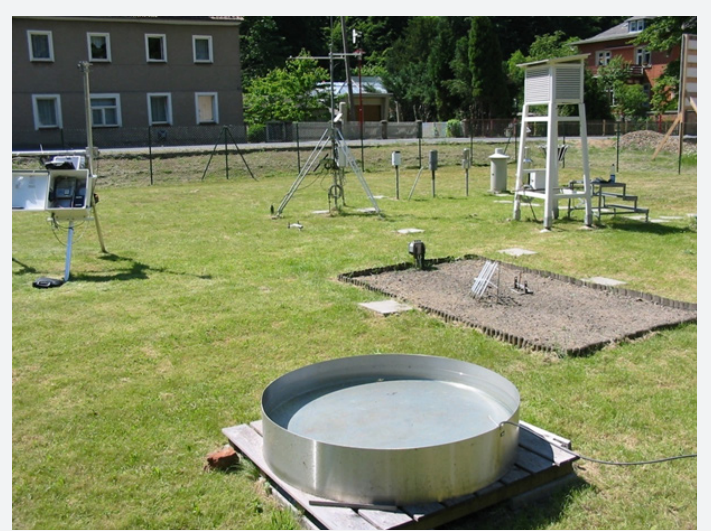

Figure 3: Standard Class-A evaporation pan at Tharandt Met. Station (Photo source: IHM, TU Dresden).
The pan used for measurement of pan evaporation is a standard Class-A pan evaporimeter (see Figure 3). The readings of the water level in the pan for every 10-minute interval ( $V^{\prime}$ ) as well as for daily basis (V) are recorded automatically by a pressure sensor device.

\section{Daily Class-A pan Evaporation at 7 a.m. and at midnight}

Using Eq. 4 and using daily water level (V) and the corresponding precipitation at 7 a.m. (P), daily pan evaporation from Class-A pan $\left(E_{p}\right)$ is calculated at 7 a.m. Similarly, $E_{p}$ at midnight is calculated using 10-minute water level ( $\left.\mathrm{V}^{\prime}\right)$ and daily precipitation at midnight (RF).

The change in water level for a day say $d\left(\Delta V_{d}{ }_{d}\right)$ at midnight is calculated by subtracting the water level at day $d$ at 23:59:00 hour $\left(\mathrm{V}_{\mathrm{d}}{ }_{\mathrm{d}}\right.$ ) from the water level at previous day (d-1) at 23:59:00 hour $\left(\mathrm{V}_{\text {d-1 }}^{\prime}\right)$; i.e., $\Delta V^{\prime}{ }_{d}=V_{d-1}^{\prime}{ }_{d}{ }^{\prime}{ }_{d} . \Delta V^{\prime}{ }_{d}$ can also be calculated by taking the sum of 144 ten-minute water level differences for each day. Both will give same result if $V^{\prime}$ has no missing values. Similarly, the change in water level for a day say $d\left(\Delta V_{d}\right)$ at 7 a.m. is calculated by subtracting the next day $($ day $d+1)$ water level at 7 a.m. $\left(V_{d+1}\right)$ from the water level at day $d$ at 7 a.m. $\left(V_{d}^{\prime}\right)$; i.e., $\Delta V_{d}=V_{d}-V_{d+1}$. Note that those days with missing $\mathrm{V}$ or $\mathrm{V}^{\prime}$ data are excluded in the calculation of $\Delta \mathrm{V}$ and $\Delta \mathrm{V}$ '.

\section{Class-A pan Evaporation $\left(E_{p}\right)$ estimation}

According to Dingman [3], pan evaporation is calculated using eq. 1 below:

$$
E=P-\left(V_{2}-V_{1}\right),[3]
$$


Where,

E pan evaporation (in $\mathrm{mm}$ )

P precipitation (in $\mathrm{mm}$ ) during $\Delta \mathrm{t}$,

$\mathrm{V}_{1} \& \mathrm{~V}_{2}$ the storages (in $\mathrm{mm}$ ) at the beginning and end of $\Delta \mathrm{t}$, respectively.

According to (WMO 1994 Sec. 9.2), the amount of evaporation that has occurred between two observations of water level in the pan (E) is calculated using Eq. 2 below:

$$
E=P \pm \Delta d,(\text { WMO } 1994 \text { Sec. 9.2) }
$$

Where,

$\mathrm{P}$ the depth of precipitation during the period between the two measurements,

$\Delta \mathrm{d}$ the depth of water added (+) to or removed (-) from the pan.

Combining Eq. 1 and Eq. 2, we get:

$$
E=P-\left(V_{2}-V_{1}\right) \pm \Delta d
$$

Modifying Eq. 3 and replacing $E$ with $\mathrm{E}_{\mathrm{pan}}$ or $\mathrm{E}_{\mathrm{p}}$, we have:

$$
E_{p}=P+\left(V_{1}-V_{2}\right) \pm \Delta d
$$

Where, $\mathrm{E}_{\mathrm{p}}$ is daily evaporation computed as the difference in Class-A pan water level on successive days, corrected for any precipitation and $\Delta \mathrm{d}$ during the period. $\mathrm{P}, \Delta \mathrm{d}, \mathrm{V}_{1}$ and $\mathrm{V}_{2}$ are as defined above. For the calculation of daily $\mathrm{E}_{\mathrm{p}}$, Eq. 4 is used throughout this article with $\Delta \mathrm{d}=0$ (because of missing $\Delta \mathrm{d}$ values). However, 41 days have information for 'special features' ('Besonderheiten_Daten') like emptying or drawing out (pumping off) some water, cleaning (e.g. using Anti-Algae chemicals) and refilling of pan (including information about confirmation of no precipitation during the refilling time); removal (fishing out) of grass, seeds, coarse dirt or suspended matter (solids) from the pan; and so forth which are excluded from the calculation of $\mathrm{E}_{\mathrm{p}}$.

Note that the maximum possible value of daily $\mathrm{E}_{\mathrm{pan}}$ in $\mathrm{mm} \mathrm{d}^{-1}$ can be set to be equal to the upper estimate of daily PET in $\mathrm{mm}$ $\mathrm{d}^{-1}\left(\mathrm{PET}_{\max }\right.$ ) (see Eq. 6). PET ${ }_{\max }$ is estimated to be the extreme maximum value of the ratio of daily net radiation (in $\mathrm{MJ} \mathrm{m}^{-2} \mathrm{~d}^{-1}$ ) calculated using Eq. 19 and (daily) latent heat of vaporization (in $\mathrm{MJ} \mathrm{kg}^{-1}$ ) calculated using Eq. 5. It is calculated with the assumption that all the available energy provided by radiation is consumed (used for vaporization).

$$
\lambda=2.501-\left(2.361 .10^{-3}\right) T,[4]
$$

Where,

$\lambda$ latent heat of vaporization (in $\mathrm{MJ} \mathrm{kg}^{-1}$ )

$\mathrm{T} \quad$ air temperature $\left(\right.$ in $\left.^{\circ} \mathrm{C}\right)$

$$
E_{p_{-} \max }=P E T_{\max }=M A X=\left(\frac{R_{n}}{\lambda}\right)
$$

Where, $\mathrm{E}_{\mathrm{p}_{-} \max }$ is the maximum possible upper limit of $\mathrm{E}_{\mathrm{p}}$ (in $\mathrm{mm} \mathrm{d}^{-1}$ ), $\mathrm{PET}_{\text {max }}$ is the maximum possible upper limit of PET (in $\mathrm{mm} \mathrm{d}^{-1}$ ), $\lambda$ latent heat of vaporization (in $\mathrm{MJ} \mathrm{kg}^{-1}$ ) and $\mathrm{R}_{\mathrm{n}}$ net radiation (in $\mathrm{MJ} \mathrm{m}^{-2} \mathrm{~d}^{-1}$ ).

Note, however, that the estimated net radiation used in this paper is based on measurements above grass level and that the Class-A pan will have a different radiation balance. Therefore,

\begin{tabular}{|c|c|c|c|c|c|c|c|c|c|c|c|}
\hline Year & 2004 & 2005 & 2006 & 2007 & 2008 & 2009 & 2010 & 2011 & 2012 & 2013 & Average \\
\hline \multicolumn{12}{|c|}{ Actual and Average of daily $\mathrm{E}_{\mathrm{p}}$ data for the available ten years (in $\mathrm{mm} \mathrm{d}^{-1}$ ) } \\
\hline 1-Apr & & & & 2.32 & & & 1.7 & 1.94 & 1.55 & & 1.88 \\
\hline 2-Apr & & 2.19 & & 2.27 & 1.72 & 1.73 & 0.74 & 2.24 & 0.77 & & 1.67 \\
\hline \multicolumn{12}{|c|}{ Actual daily $\mathrm{E}_{\mathrm{p}}$ data (in $\mathrm{mm} \mathrm{d}^{-1}$ ); missing values filled using average values } \\
\hline 1-Apr & 1.88 & 1.88 & 1.88 & 2.32 & 1.88 & 1.88 & 1.7 & 1.94 & 1.55 & 1.88 & 1.88 \\
\hline 2-Apr & 1.67 & 2.19 & 1.67 & 2.27 & 1.72 & 1.73 & 0.74 & 2.24 & 0.77 & 1.67 & 1.67 \\
\hline
\end{tabular}
Eq. 6 can be a suited check for PET estimations according to Haude, Wendling, and Penman and ET out only a rough check for $\mathrm{E}_{\mathrm{p}}$. $\mathrm{E}_{\mathrm{p} \_ \text {max }}$ resulted $7.198(7.2) \mathrm{mm} \mathrm{d}^{-1}$.

Table 1: Example for filling missed daily values of $E_{p}$ (for $1^{\text {st }}$ and $2^{\text {nd }}$ of April) using ten-year daily averages of $E_{p}$ for the available ten years.

Monthly $\mathrm{E}_{\mathrm{p}}$ is calculated by aggregation of daily $\mathrm{E}_{\mathrm{p}}$ values for months from April to October of each year. Note however that few days at the beginning of April and at the end of October had considerable missing daily $\mathrm{E}_{\mathrm{p}}$ values. Hence, the average values of daily $E_{p}$ for the available ten years (from 2004 to 2013) is used for filling missing daily $\mathrm{E}_{\mathrm{p}}$ values of each year (see Table 1 ).

\section{Results and Discussion}

\section{Comparing Class-A pan evaporation at 7 a.m. and at midnight}

Daily values of pan evaporation from Class-A pan $\left(E_{p}\right)$ were calculated at 7 a.m. and at midnight using Eq. 4. The calculation was performed for $\mathrm{n}=2145$ and 1971 days \{from daily P and RF data and their corresponding fully available daily (V) and tenminutes (V') water level data, respectively\}.

Generally daily $\mathrm{E}_{\mathrm{p}}$ at 7 a.m. resulted in greater values than daily Ep at midnight. It also resulted in less (121) negative values whereas daily $E_{p}$ at midnight resulted in more (213) negative values (see Table 2). Thus, comparatively $\mathrm{E}_{\mathrm{p}}$ at 7 a.m. has the advantage of having a greater number of values with a smaller number of negative values which made it preferable to $E_{p}$ at midnight. Therefore, $\mathrm{E}_{\mathrm{p}}$ calculated at 7 a.m. is selected in this article. Its missing values are filled using $\mathrm{E}_{\mathrm{p}}$ at midnight values following the description in section 3.2. 
Table 2: Comparison of 7a.m. and midnight daily $\mathrm{E}_{\mathrm{p}}$ values at Tharandt over ten years for three ranges of values (cases) and before application of any correction.

\begin{tabular}{|c|c|c|c|}
\hline Case A: for all values of $E_{p}$ & $E_{p}$ at 7 a.m. & $\mathrm{E}_{\mathrm{p}}$ at midnight & $\mathbf{E}_{\mathrm{pd}}^{\mathrm{a}}$ \\
\hline Number of values (n) & 2145 & 1971 & $1966 \mathrm{~b}$ \\
\hline Number of days with $E_{p} \geq 7.2\left[\mathrm{~mm} \mathrm{~d}^{-1}\right]$ & 28 & 21 & 5 \\
\hline Number of days with $E_{p} \leq-0.5 \mathrm{~mm} \mathrm{~d}^{-1}$ & 43 & 84 & 85 \\
\hline Number of days with $\mathrm{E}_{\mathrm{p}}<0 \mathrm{~mm} \mathrm{~d}^{-1}$ & 121 & 213 & 686 \\
\hline Extreme maximum value $\left[\mathrm{mm} \mathrm{d}^{-1}\right]$ & 77.52 & 79.43 & 13.66 \\
\hline Extreme minimum value $\left[\mathrm{mm} \mathrm{d}^{-1}\right]$ & -77.88 & -78.4 & -41.37 \\
\hline Average $\left[\mathrm{mm} \mathrm{d}^{-1}\right]$ & 2.32 & 2.16 & 0.21 \\
\hline Case B: for $-0.5 \mathrm{~mm} \mathrm{~d}^{-1} \leq E_{p} \leq 7.2 \mathrm{~mm} \mathrm{~d}^{-1}$ & $E_{p}$ at 7 a.m. & $\mathrm{E}_{\mathrm{p}}$ at midnight & $\mathbf{E}_{\mathrm{pd}}^{\mathrm{a}}$ \\
\hline Number of values (n) & $1998(1836)^{\mathrm{c}}$ & $1866(1836)^{c}$ & 1836 \\
\hline Average $\left[\mathrm{mm} \mathrm{d}^{-1}\right]$ & $2.23(2.23)^{\mathrm{d}}$ & $2.03(2.03)^{\mathrm{d}}$ & 0.2 \\
\hline Case $C$ : for $0 \leq E_{p} \leq 7.2 \mathrm{~mm} \mathrm{~d}^{-1}$ & $E_{p}$ at 7 a.m. & $\mathrm{E}_{\mathrm{p}}$ at midnight & $E_{p d}^{a}$ \\
\hline Number of values (n) & $1871(1699)^{\mathrm{c}}$ & $1738(1699)^{c}$ & 1699 \\
\hline Average $\left[\mathrm{mm} \mathrm{d}^{-1}\right]$ & $2.37(2.39)^{\mathrm{d}}$ & $2.21(2.21)^{\mathrm{d}}$ & 0.19 \\
\hline
\end{tabular}

${ }^{a} E_{p d}$ is used to denote daily $E_{p}$ at 7 a.m. minus daily $E_{p}$ at midnight

bout of the 1966 days for two days both $E_{p}$ at 7 a.m. and $E_{p}$ at midnight had equal values

cthe number in parenthesis is the number of days where both $E_{p}$ at 7 a.m. and $E_{p}$ at midnight had values;

'the corresponding average value.

To evaluate the error among case A, case B, and case C of Table 2, the methods for comparison and evaluation of models which are discussed and applied by considering the daily $\mathrm{E}_{\mathrm{p}}$ at

midnight as observation values (i.e., $\mathrm{x}$ or $\mathrm{Oi}$ ) and daily $\mathrm{E}_{\mathrm{p}}$ at 7 a.m. as model (estimated) values (i.e., y or Pi).

Table 3: Brief statistical summary for comparison of daily $E_{p}$ at 7 a.m. and at midnight for three ranges of values (cases) before application of any correction.

\begin{tabular}{|c|c|c|c|c|c|c|c|c|c|}
\hline & $\mathbf{n}$ & $\mathbf{a}$ & $\mathbf{b}$ & $\mathbf{R}^{2}$ & NSE & MAE & RMSE & RSR & MPE \\
\hline Unit & - & - & - & - & - & $\mathrm{mm} \mathrm{d}^{-1}$ & $\mathrm{~mm} \mathrm{~d}^{-1}$ & - & $\%$ \\
\hline Case A & 1966 & 0.95 & -0.09 & 0.93 & 0.93 & 0.48 & 1.4 & 0.27 & $7.10(\mathrm{n}=1312)$ \\
\hline Case B & 1836 & 0.91 & 0.39 & 0.87 & 0.95 & 0.35 & 0.57 & 0.23 & $7.10(\mathrm{n}=1285)$ \\
\hline Case C & 1699 & 0.91 & 0.38 & 0.86 & -1012 & 0.34 & 0.56 & 31.83 & $7.10(\mathrm{n}=1284)$ \\
\hline
\end{tabular}

For all the three cases, the p-value was 0.05 (not shown). It indicated that existence of statistically significant difference between daily $\mathrm{E}_{\mathrm{p}}$ at 7 a.m. and daily $\mathrm{E}_{\mathrm{p}}$ at midnight values at $5 \%$ significance level could not be concluded. In all cases, the MPE was around 7.1\%; which means that $\mathrm{E}_{\mathrm{p}}$ at 7 a.m. values were relatively larger by $7.1 \%$ as compared to $\mathrm{E}_{\mathrm{p}}$ at midnight values (see Table 3).

For case A, three 'goodness-of-fit' measures ( $\mathrm{R}^{2}$, NSE, and RSR) showed 'very good' relationship between daily Ep values at midnight and at 7 a.m. (see Table 3). However, the RMSE was comparatively the biggest. Moreover, in case A (see Table 2) daily $E_{p}$ at 7 a.m. and at midnight resulted in 43 and 84 days with $\mathrm{E}_{\mathrm{p}} \leq-0.5 \mathrm{~mm} \mathrm{~d}^{-1}$ and in 28 and 21 days with $\mathrm{E}_{\mathrm{p}} \geq 7.2 \mathrm{~mm}$ $\mathrm{d}^{-1}$, respectively. Thus, comparatively, using case B or case $\mathrm{C}$ was better than using case A. As compared to case C, Case B had the advantage of using more values with better NSE and RSR. Hence, it can be concluded that case B was the best.
Note that in this article the minimum possible $E_{p}$ from Class-A pan for the climate condition of Germany is limited to $\geq-0.5 \mathrm{~mm} \mathrm{~d}^{-1}$ in an assumption that there could be a maximum condensation of up to $0.5 \mathrm{~mm} \mathrm{~d}^{-1}$. Similarly, the maximum possible $\mathrm{E}_{\mathrm{p}}$, as calculated using Eq. 6 , is limited to $\leq 7.2 \mathrm{~mm} \mathrm{~d}^{-1}$ [5-12].

\section{Filling missing values of $E_{p}$ at 7 a.m.}

Case B resulted in a regression equation (see Eq. 7 and Figure 4) which is used for filling the missing values of daily $E_{p}$ at 7 a.m. by using daily $\mathrm{E}_{\mathrm{p}}$ at midnight values as given below:

$\mathrm{E}_{\mathrm{p}}$ at 7 a.m. (in $\left.\mathrm{mm} \mathrm{d}^{-1}\right)=0.908 \mathrm{E}_{\mathrm{p}}$ at midnight (in $\left.\mathrm{mm} \mathrm{d}^{-1}\right)+$ $0.385 \mathrm{~mm} \mathrm{~d}^{-1}$

In Eq. 7 a zero offset was expected; however, an offset of 0.385 had resulted. The cause for non-zero offset might be instrument error; the sensitivity of the pressure sensor instrument for same pressure (depth of pan water) at 7 a.m. and at midnight 
might have slight difference. Assuming no instrument error, for example for case $\mathrm{B}$, out of 1836 days, $\mathrm{E}_{\mathrm{p}}$ at 7 a.m. was larger than $\mathrm{E}_{\mathrm{p}}$ at midnight for 1184 days (64.5\% of the days). Note also that
$\mathrm{R}^{2}=0.87$ in Eq. 7 indicates that daily $\mathrm{E}_{\mathrm{p}}$ at 7 a.m. explains $87 \%$ of the variability in the observed data (daily $\mathrm{E}_{\mathrm{p}}$ at midnight values).

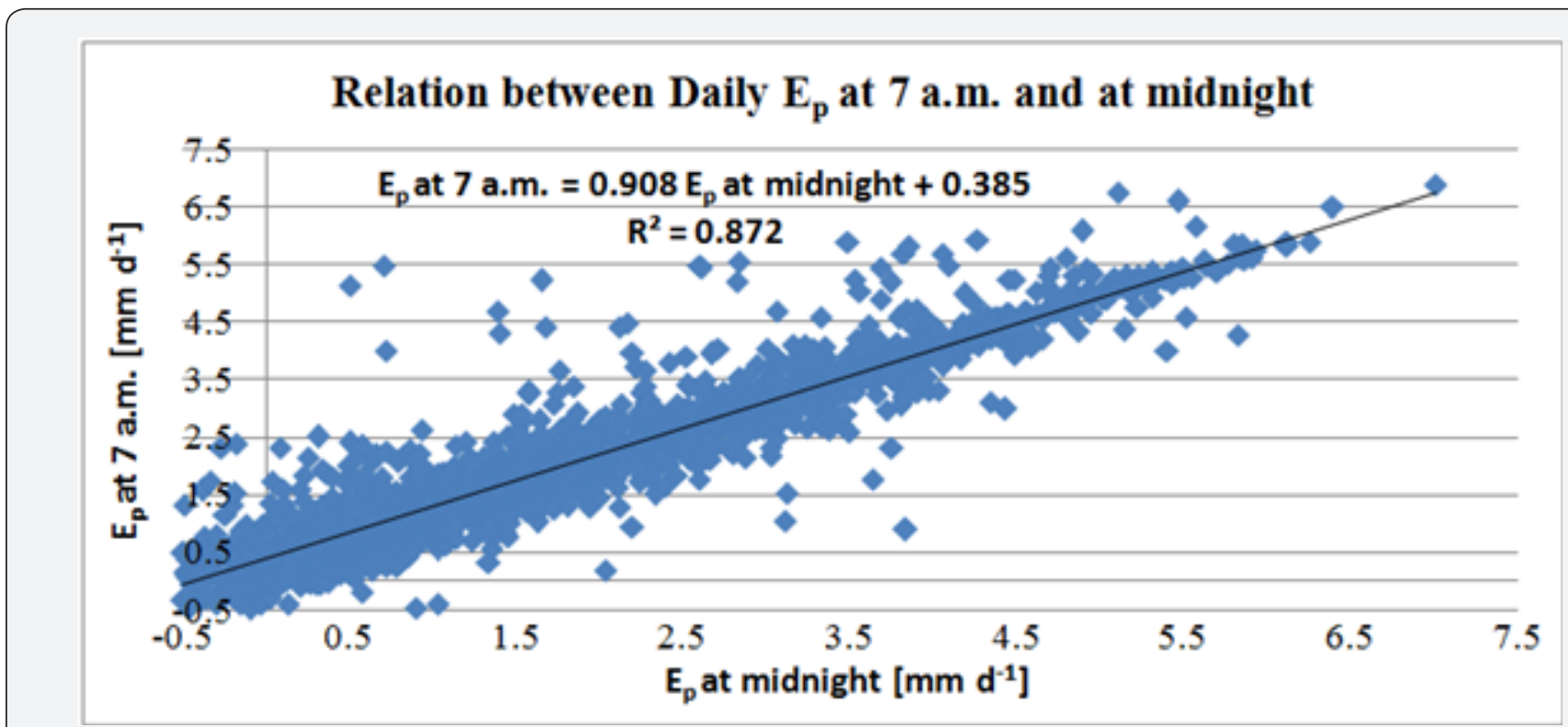

Figure 4: Relation between daily $E_{p}$ at 7 a.m. and daily $E_{p}$ at midnight at Tharandt for case $B\left(-0.5 \leq E_{p} \leq 7.2\right)$ from 2004 to 2013 ( $\left.n=1836\right)$.

Therefore, out of 2145 daily values of $\mathrm{E}_{\mathrm{p}}$ at 7 a.m. the values which are missing and were not in the range between -0.5 and $7.2 \mathrm{~mm} \mathrm{~d}^{-1}$ are corrected using $1971 \mathrm{E}_{\mathrm{p}}$ at midnight values (Table
2). Accordingly, 24 values of $E_{p}$ at 7 a.m. are filled or replaced using Eq. 7 while other 47 values are omitted and 2098 (2145 minus 47) values of $E_{p}$ at 7 a.m. are used for next analyses.

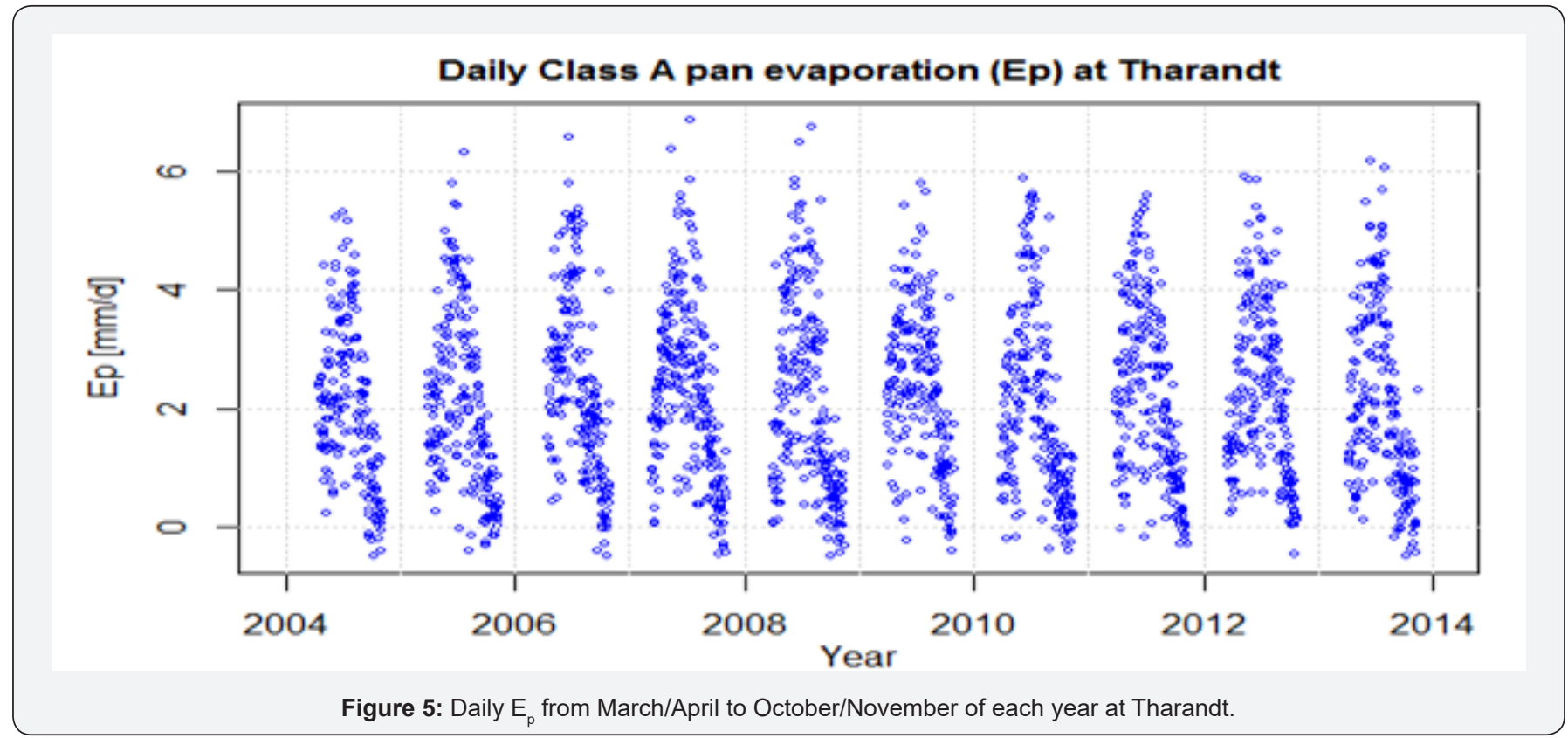

\section{Estimated class-A pan evaporation $\left(E_{p}\right)$}

As discussed in the above sections, daily Class-A pan evaporation $\left(E_{p}\right)$ is calculated using daily $E_{p}$ at 7 a.m. values for $\mathrm{n}=2098$ days from March/April to October/November.
Accordingly, the daily $\mathrm{E}_{\mathrm{p}}$ resulted in average, extreme maximum and extreme minimum values of approximately $2.16,6.87$ and $-0.50 \mathrm{~mm} \mathrm{~d}^{-1}$, respectively. Throughout the 2004 to 2013 period, it was above $6 \mathrm{~mm} \mathrm{~d}-1$ for only 8 days (see Figure 5 ). 
The ten-year daily average $\mathrm{E}_{\mathrm{p}}$ calculated from April to October (see Figure 6) was approximately between 3 and $4 \mathrm{~mm}$ $\mathrm{d}^{-1}$ from mid of May to mid of August except for one day in July where it was around $4.28 \mathrm{~mm} \mathrm{~d}^{-1}$. In the rest of the months it was between 3 and $1 \mathrm{~mm} \mathrm{~d}^{-1}$ except from mid of September to October where it declined to between $1 \& 0.14 \mathrm{~mm} \mathrm{~d}^{-1}$.

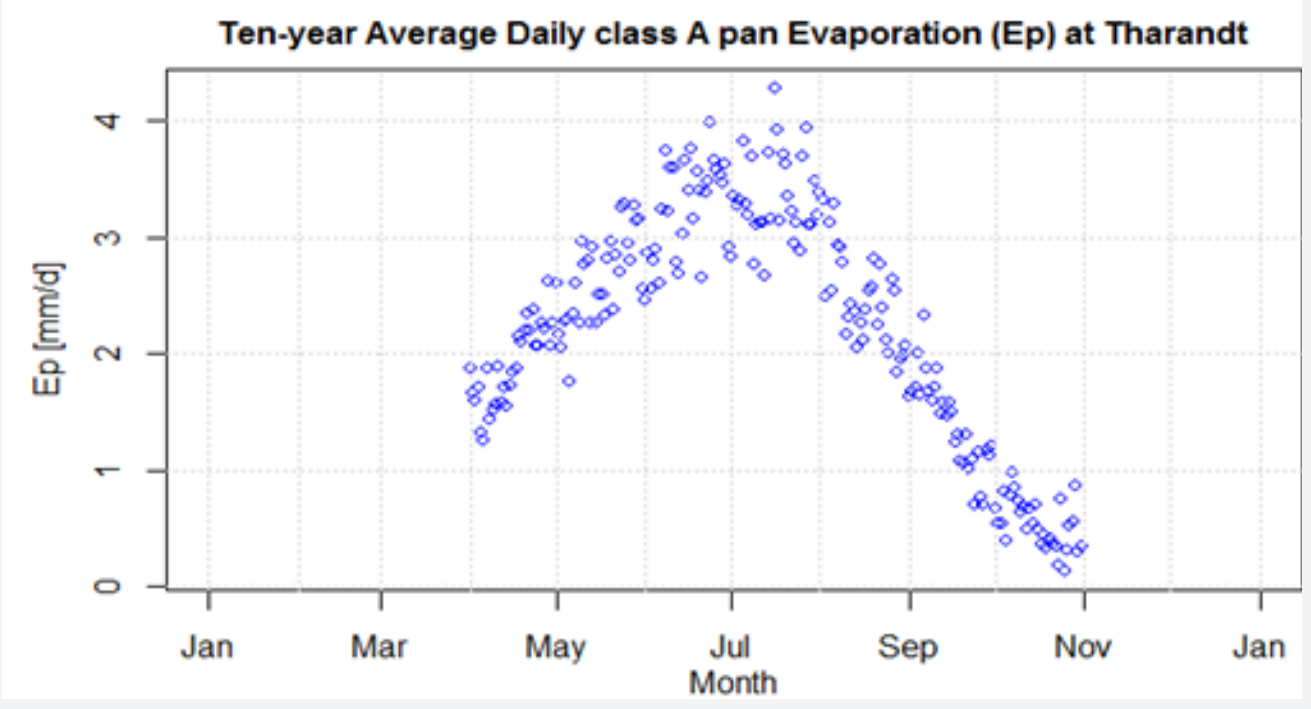

Figure 6: Ten-year (from 2004 to 2013) average of daily $E_{p}$ at Tharandt from April to October.

As shown below in Figure 7, the monthly total $\mathrm{E}_{\mathrm{p}}$ calculated from April to October had the highest value in July $(103.2 \mathrm{~mm})$ followed by June $(97.3 \mathrm{~mm})$, May $(81.8 \mathrm{~mm})$ and August $(77.4 \mathrm{~mm})$. The least value of $E_{p}$ was in October $(17.3 \mathrm{~mm})$ followed by September (42.4mm) and April (57.0mm). Figure 7 also shows that the peak value was in July for five years, in June for four years and in May for one year.

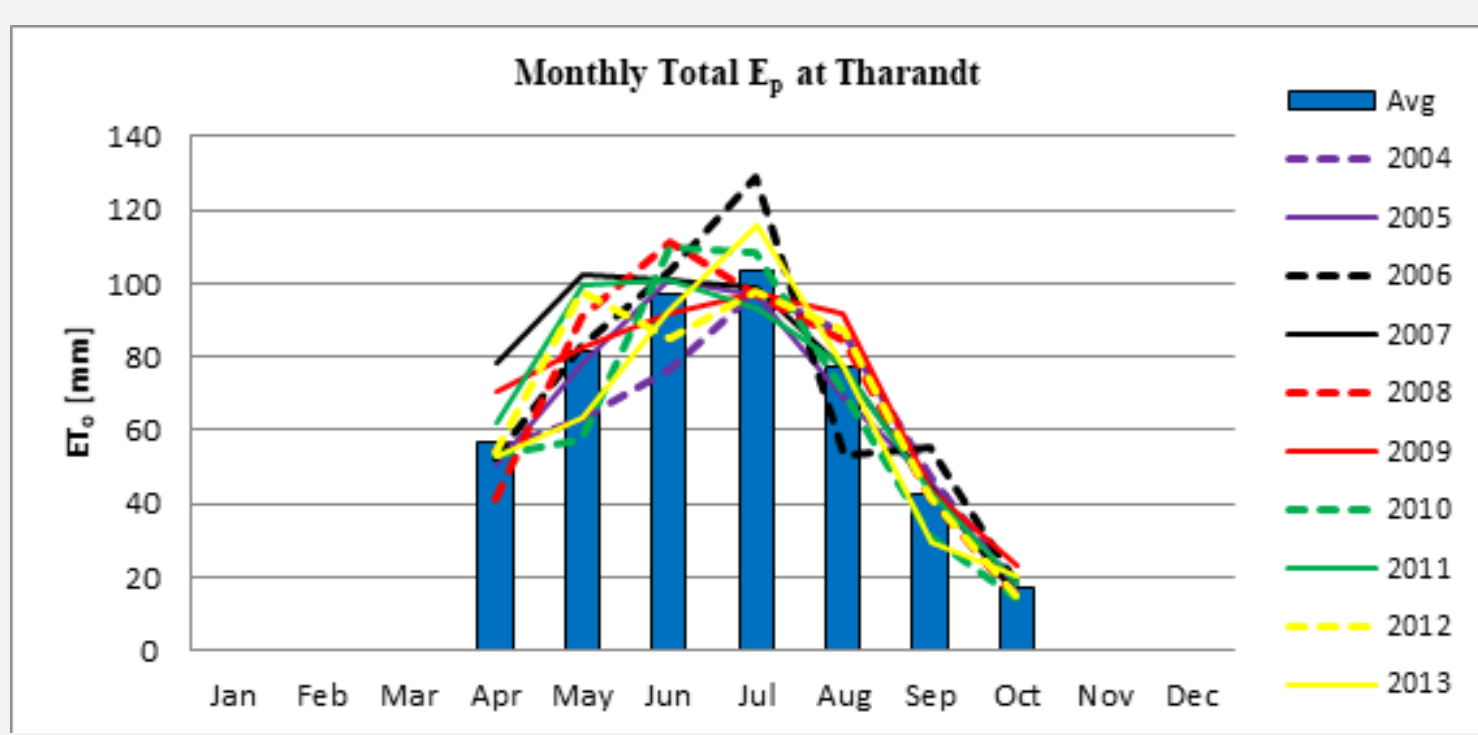

Figure 7: Yearly and Average of ten years Monthly Total $E_{p}$ at Tharandt from 2004 to 2013.

\section{Understanding $\mathrm{E}_{\mathrm{pd}}$ (for case B)}

$\mathrm{E}_{\mathrm{pd}}$ (daily $\mathrm{E}_{\mathrm{p}}$ at 7 a.m. minus daily $\mathrm{E}_{\mathrm{p}}$ at midnight) means a next day $($ Day $n+1)$ 'night time' $E_{p}$ minus a previous day (Day n) 'night time' $\mathrm{E}_{\mathrm{p}}$ (see Figure 1). Note that 'night time' is used in this thesis to represent the time from midnight to 7 a.m.
Like Table 3, Figure $8 \& 9$ graphically show that there was a general 'good' relationship between $E_{p}$ at 7 a.m. and $E_{p}$ at midnight; $E_{p d}$ was between $\pm 1 \mathrm{~mm} \mathrm{~d}^{-1}$ for majority of the days. Daily $\mathrm{E}_{\mathrm{pd}}$ was $>1$ and $<-1 \mathrm{~mm} \mathrm{~d}^{-1}$ for 107 and 14 days, respectively. 


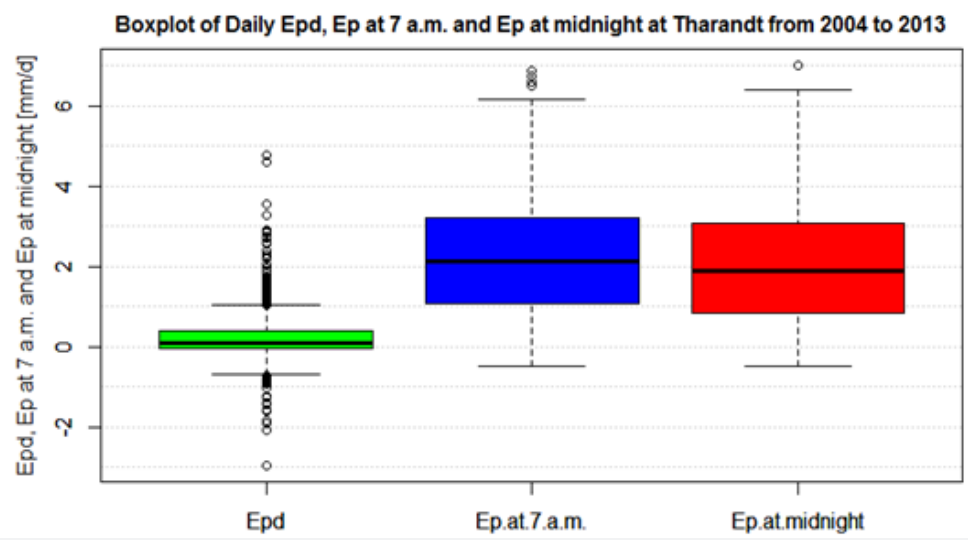

Figure 8: Box plot of daily values of $E_{p d}, E_{p}$ at 7 a.m. and $E_{p}$ at midnight at Tharandt from 2004 to $2013(n=1836)$.

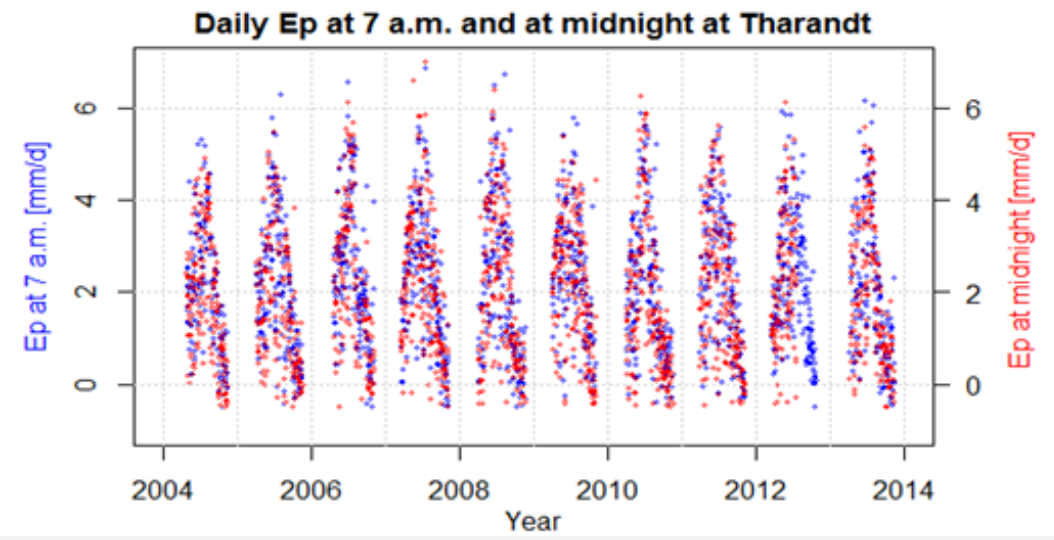

Figure 9: Time series of daily $E_{p}$ at 7 a.m. $(n=1998)$ and at midnight $(n=1866)$ at Tharandt from 2004 to 2013.

In Figure 10 the regression line shows only a slight increment in $\mathrm{E}_{\mathrm{pd}}$. The increase was very small; from about $0.1 \mathrm{~mm}$ to $0.4 \mathrm{~mm}$. That means an increase of around $0.3 \mathrm{~mm}$ per
10 years. Moreover, $\mathrm{R}^{2}$ was too low. Thus, the trend (existence of a systematic increase or decrease) of $\mathrm{E}_{\mathrm{pd}}$ can be neglected.

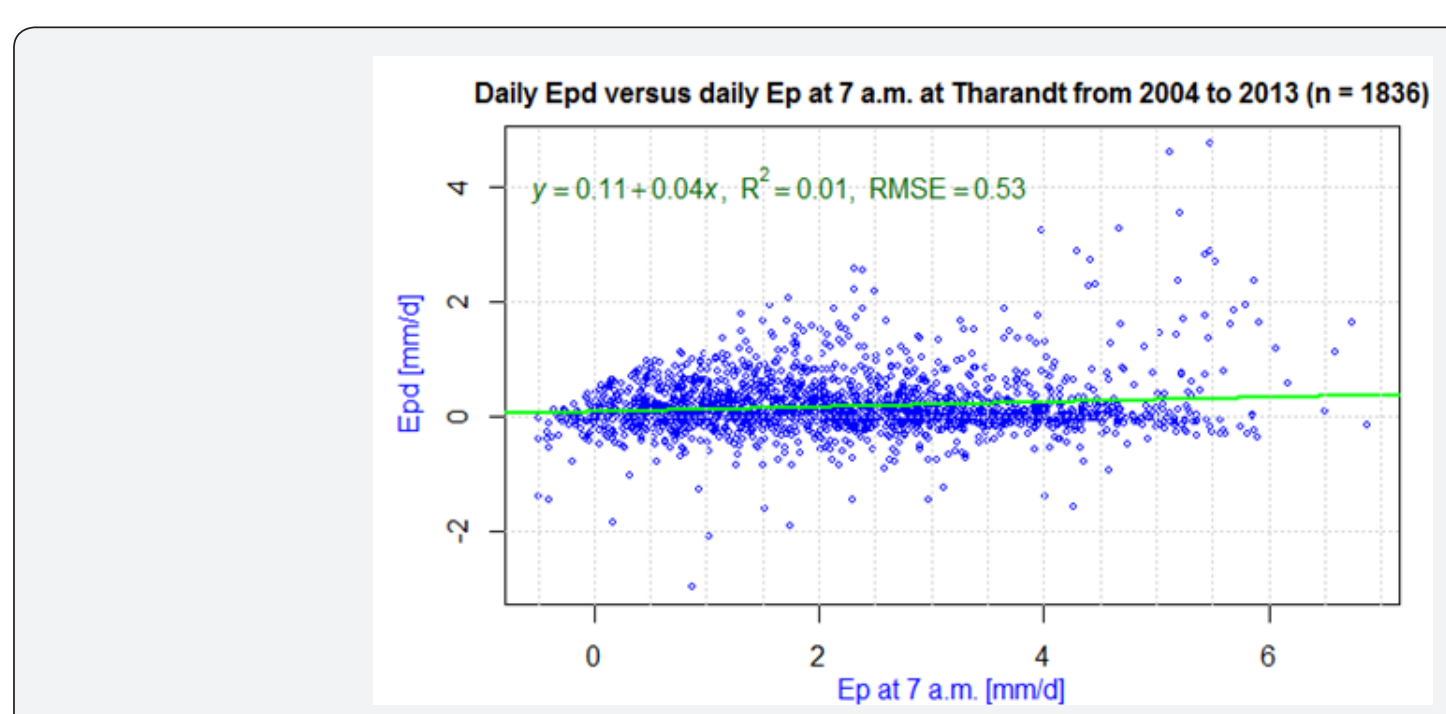

Figure 10: Daily $E_{p d}$ versus daily $E_{p}$ at 7 a.m. at Tharandt from 2004 to $2013(n=1836)$. 
If all other conditions are constant or if instrument and calculation errors are negligible, $\mathrm{E}_{\mathrm{pd}}$ shows the 'night time' difference of $\mathrm{E}_{\mathrm{p}}$ (in $\mathrm{mm} \mathrm{d}^{-1}$ ) between two consecutive days. Also, because:

1. there was no a systematic significant trend, shift or lag (Figure 9 and Figure 10);

2. daily Ep at 7 a.m. and at midnight have good correlation $\left(\mathrm{R}^{2}=0.87\right)$; and

3. $\mathrm{E}_{\mathrm{pd}}>1.5 \mathrm{~mm} \mathrm{~d}^{-1}$ for 48 days and $<-1.5 \mathrm{~mm} \mathrm{~d}^{-1}$ for 6 days; it can be concluded that the 'night time' daily $\mathrm{E}_{\mathrm{p}}$ had to be greater than $1.0 \mathrm{~mm} \mathrm{~d}^{-1}$ for 54 days.

\section{Conclusion}

The accuracy of the self-recording ten-minute and daily water level measurements from Class-A pan at Tharandt from 2004 to 2013 could be considered as very good. However, the accuracy of the pressure sensor instrument which is used to automatically measure Class-A pan water level shall be carefully checked for the available daily and ten-minute measurements; it might have sensitivity to other than pressure or water depth difference in the pan. Hence, the sensitivity of the pressure sensor instrument at 7 a.m. and at midnight for same pressure (depth of pan water) might have slight difference.

Missing values of daily $\mathrm{E}_{\mathrm{p}}$ at 7 a.m. can be filled using 0.908 $\times$ daily $\mathrm{E}_{\mathrm{p}}$ at midnight values +0.385 (Eq. 7). In Eq. 7, the cause for non-zero offset ( 0.385 ) could be instrument error. Assuming no instrument error, at Tharandt from 2004 to 2013, out of 1836 days, $\mathrm{E}_{\mathrm{pd}}$ was larger than zero for 1184 days $(64.5 \%$ of the days). It is also concluded that the 'night time' daily $\mathrm{E}_{\mathrm{p}}$ had to be $\geq 1.0 \mathrm{~mm} \mathrm{~d}^{-1}$ for 54 days. The existence of 'night time' $E_{p}$ might have made the comparison of $\mathrm{E}_{\mathrm{p}}$ at 7 a.m. and $\mathrm{E}_{\mathrm{p}}$ at midnight a bit complicated.

The sensitivity of the automatic Class-A pan water level measuring instrument to other than pressure (water depth difference in the pan) must be checked. If there was no measurement error and if 'night time' $E_{p}$ is negligible, then the question: 'Why Ep at 7 a.m. is greater than $\mathrm{E}_{\mathrm{p}}$ at midnight for majority (65\%) of the days?' may require further study.

\section{Acknowledgement}

For every good thing, I praise GOD and GOD'S MOTHER above all. I particularly thank Virgin Mary or 'Tsadkane Mariam'

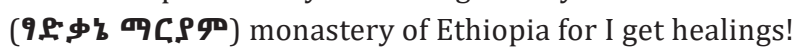

Very special thanks to my official supervisors Prof. Dr. Christian Bernhofer and Dr. Uta Moderow for their excellent supervision, for providing me all the needed data in advance, and for their friendly approach throughout my research. Very special thanks to Mr. Endalkachew Bekele for giving me valuable guidance and for editing the text for publishing. I also thank Mr. Thomas Pluntke, Mr. Philipp Körner and their colleague(s) for their support and for providing me meteorological data.

I also want to thank all my elementary and high school teachers especially my mathematics teachers Mrs. Abebech ('Tiye Abebech') and Mr. Abebe ('Gash Abe'). I also want to use this chance to thank all kind persons who (have) supported me in my life.

Last but the best, I would like to thank my wife and my family and friends for their crucial support and for sharing love and happiness throughout my life.

\section{References}

1. Dingman SL (2002) Physical Hydrology. ( $2^{\text {nd }}$ edn), Upper Saddle River, N.J., Prentice Hall.

2. McMahon TA, Peel MC, Lowe L, Srikanthan R, McVicar TR (2013) Estimating actual, potential, reference crop and pan evaporation using standard meteorological data: a pragmatic synthesis. Hydrol Earth Syst Sci 17: 1331-1363.

3. Dingman SL (1994) Physical Hydrology. ( $3^{\text {rd }}$ edn).

4. Allen RG, Pereira LS, Raes D, Smith M (1998) Crop evapotranspiration: Guidelines for computing crop water requirements. FAO Irrig. and Drain. Paper No. 56, Food and Agricultural Organization of the United Nations, Rome, Italy.

5. ASCE-EWRI (2005) The ASCE Standardized Reference Evapotranspiration Equation. Task Committee (TC) on Standardization of Reference Evapotranspiration. In: Allen RG, Walter IA, Elliott R, Howell T, Itenfisu D, et al. (Eds.), Environmental and Water Resources Institute (EWRI) of the American Society of Civil Engineers (ASCE).

6. Filho DBF, Paranhos R, Rocha EC, Batista M, Silva JA, et al. (2013) When is statistical significance not significant? Brazilianpoliticalsciencereview.

7. Irmak S, Haman DZ, Jones JW (2002) Evaluation of Class-A Pan Coefficients for Estimating Reference Evapotranspiration in Humid Location. J Irrig Drain Eng ASCE 128(3): 153-159.

8. Khan AU, Hildreth WB (2003) Case studies in public budgeting and financial management. New York, N.Y: Marcel Dekker, USA.

9. Legates DR, McCabe GJ (1999) Evaluating the use of "goodness-of-fit" measures in hydrologic and hydroclimatic model validation. Water Resources Research 35(1): 233-241.

10. Lhomme JP (2016) Towards a rational definition of potential evaporation. Hydrology and Earth System Sciences 1(2): 257-264.

11. Mohammadi M, Ghahraman B, Davary K, Liaghat AM, Bannaya M (2012) Pan coefficient $\left(\mathrm{K}_{\mathrm{p}}\right)$ estimation under uncertainty on fetch. Meteorol Atmos Phys 117(1-2): 73-83.

12. Moriasi DN, Arnold GJ, Van Liew MW, Bingner RL, Harmel RD, et al. (2007) Model Evaluation Guidelines for Systematic Quantification of Accuracy in Watershed Simulation. American Society of Agricultural and Biological Engineers 50(3): 885-900. 
This work is licensed under Creative Commons Attribution 4.0 License

DOI: 10.19080/IJESNR.2019.19.556003
Your next submission with Juniper Publishers will reach you the below assets

- Quality Editorial service

- Swift Peer Review

- Reprints availability

- E-prints Service

- Manuscript Podcast for convenient understanding

- Global attainment for your research

- Manuscript accessibility in different formats ( Pdf, E-pub, Full Text, Audio)

- Unceasing customer service

Track the below URL for one-step submission https://juniperpublishers.com/online-submission.php 